Research Article

\title{
Influence of Real-Time Heating on Mechanical Behaviours of Rocks
}

\author{
Bin Gu, ${ }^{1,2}$ Zhijun Wan $\mathbb{D}^{1,2}$ Yuan Zhang, ${ }^{2}$ Yangsheng $M a^{3}$ and Xiaodong Bernard $\mathrm{Xu}^{4}$ \\ ${ }^{1}$ Key Laboratory of Deep Coal Resource Mining, China University of Mining \& Technology, Ministry of Education of China, \\ Xuzhou 221116, China \\ ${ }^{2}$ School of Mines, China University of Mining \& Technology, Xuzhou 221116, China \\ ${ }^{3}$ School of Mines, Shanxi Normal University, Linfen 041000, China \\ ${ }^{4}$ Department of Chemical Engineering, Monash University, Clayton, VIC 3800, Australia
}

Correspondence should be addressed to Zhijun Wan; zhjwan@cumt.edu.cn

Received 4 March 2020; Accepted 26 May 2020; Published 11 August 2020

Academic Editor: Zhi-Qiang Yin

Copyright ( $) 2020$ Bin Gu et al. This is an open access article distributed under the Creative Commons Attribution License, which permits unrestricted use, distribution, and reproduction in any medium, provided the original work is properly cited.

\begin{abstract}
The rock mechanical properties under the effect of high temperature present a great significance on underground rock engineering. In this paper, the mechanical properties of sandstones, marbles, and granites under real-time heating were investigated with a servo-controlled compression apparatus. The results show that mechanical behaviours of all the three types of rocks are influenced by real-time heating to different degrees. Due to thermal cracking, the uniaxial compressive strengths decrease as the heating temperature rises from room temperature to $400^{\circ} \mathrm{C}$. Above $400^{\circ} \mathrm{C}$, the sandstone exhibits a significant increase in UCS because of the sintering reaction. The sintering enlarges the contact area and friction between crystal grains in the sandstone, which strengthens the bearing capacity. For marbles, the UCS continues to decrease from $400^{\circ} \mathrm{C}$ to $600^{\circ} \mathrm{C}$ due to thermal cracking. However, the carbonate in the marble begins to decompose after $600^{\circ} \mathrm{C}$. The generated particles would fill the cracks in the marble and increase the strength. For granites, their UCS presents a sharp decline after $400^{\circ} \mathrm{C}$ because of thermal cracking. For all rock elastic modulus, they present a decreasing trend, and this indicates that the rock's ability to resist deformation gradually weakens under the effect of temperature. In general, rock mechanical behaviours under real-time heating differ from those in normal situations, and use of the parameters presented here is important for underground rock engineering related to high temperature and can improve the precision in theoretical and numerical analysis.
\end{abstract}

\section{Introduction}

Physical and mechanical properties of the rock have attracted significant attention in a number of research fields, such as coal mining, underground coal gasification, and geothermal resource exploitation [1-3]. In physical experimental tests, characteristics of rock matrix permeability, failure mode, and mechanical parameters present large changes after loading process $[4,5]$. There is a growing demand for extensive understanding of rock behaviours under the influence of heating, especially above $200^{\circ} \mathrm{C}$ where material properties change dramatically [6]. Previous research on rock properties generally focused on sandstones, granites, and calcarenites. It is well known that rock mechanical properties and the corresponding internal mechanism at high temperature are dependent on the rock type. Previous studies have shown that thermal cracking, phase transition, and decomposition all contribute to variation of rock mechanical properties $[7,8]$.

Sandstone is a typical sedimentary rock in the Earth crust, and some scholars have conducted a series of experiments on its physical and mechanical characteristics under different experimental conditions, such as cyclic loads [9-11] and crack angle [12]. However, with temperature changes, sandstones present a different variation than those in normal condition. Török and Hajpál [13] found that the cementing agents and minerals of sandstones undergoing thermal treatment affect the rock physicomechanical 
properties. Santos et al. [14] conducted a series of tests on sandstones (including some artificial materials) under different heating regimes and reported no clear distinctions of rock mechanical properties below $200^{\circ} \mathrm{C}$, while mechanical properties decrease uniformly with a temperature above $200^{\circ} \mathrm{C}$. In an experimental study, Mccabe et al. [15] measured weight loss and visual surface damage to sandstones after exposure to fires and reported that the fracture structure and the soot are the primary factors that affect rock mechanical properties. The soot is hydrophobic in character, so surface permeability is reduced. The decomposition of minerals after exposure to high temperature results in an expansion of internal rock fractures, leading to weight loss and surface visual damage. Liu and $\mathrm{Xu}$ [16] performed a series of tests on the uniaxial compressive strength (UCS) of sandstones up to $1000^{\circ} \mathrm{C}$ and found that the temperature threshold for brittleductile deformation of sandstones is $600^{\circ} \mathrm{C}$. Within this temperature range, the UCS generally decreases with increase in the temperature; UCS changes are insignificant below $800^{\circ} \mathrm{C}$ but increase slightly above $800^{\circ} \mathrm{C}$ and then decrease sharply further, as does the elastic modulus. Many similar physical tests have been conducted to measure the UCS and elastic modulus of sandstone [17-19], as summarized by Tian et al. [20]. Overall, under the effect of temperature, physicomechanical properties of sandstones differ from those in natural condition.

These factors also affect the mechanical properties of calcarenites [21-24]. Yavuz and Topal [25] conducted experiments to study the effect of drying temperature on marble physicomechanical properties and reported that higher temperature causes significant damage. Mao et al. [26] concluded that mechanical properties of limestone change pronouncedly above $600^{\circ} \mathrm{C}$ when samples undergo plastic deformation. The p-wave velocity of the carbonate rock has been reported to negatively correlate with temperature [27]. Carbonate rocks at $800^{\circ} \mathrm{C}$ have also been reported to undergo a sharp decrease in rock's UCS compared with sandstone and granite due to the composition of the carbonate [24].

However for granites, many studies concentrate on burial depths of granite and the fracture mode [28-30]. Under the effect of temperature, previous studies have shown a small decrease in UCS with temperature below $400^{\circ} \mathrm{C}$, followed by a significant decrease above $400^{\circ} \mathrm{C}$ [31-33]. Chen et al. [34] reported a decrease in granite UCS, elastic modulus, and fracture toughness up to $800^{\circ} \mathrm{C}$, above which no further changes were observed. A freeze-thaw cycling test demonstrated that granite peak strain increases with temperature, while UCS and elastic modulus decrease [35]. Kumari et al. [36] conducted a series of hydraulic fracturing experiments and reported a linear reduction of granite breakdown pressure with a temperature up to $300^{\circ} \mathrm{C}$. Upon heating of granite samples, the evaporation of free water, asymmetrical thermal expansion, phase transition of quartz, and thermal cracking induced by thermal stress contribute to the propagation of cracks, all of which affect the mechanical properties of granite [6,37-39].

The literature shows that rock mechanical properties fluctuate only slightly with temperature rising up to approximately $400^{\circ} \mathrm{C}-600^{\circ} \mathrm{C}$, above which substantial changes occur. The main factors that influence rock mechanical properties are thermal cracking and the asymmetric thermal expansion of minerals [18]. In terms of specific applications (e.g., underground coal gasification, enhanced geothermal system, and even building fire), the rock matrix is under the influence of a range of real-time temperatures. Under the real-time temperature, the rock mechanical behaviour varies significantly. The majority of previous studies are normally addressed to rock samples with heat treatment rather than under real-time temperature, and it is insufficient for conducting engineering design due to different rock categories in rock underground engineering.

In this study, we investigated igneous, sedimentary, and metamorphic rocks to better understand the different rock mechanical behaviours at high temperature and to establish a framework to compare mechanical properties of different rocks during real-time heating. The results obtained here have important implications for the prediction of rock behaviour in real high-temperature scenarios and can prevent serious damage with the help of a new technique, like 3D seismic technology [40]. We compare the rock failure mechanism of each type of rocks with a particular focus on UCS and elastic modulus.

\section{Materials and Methods}

2.1. Sample Collection and Specifications. Sandstone and marble samples were, respectively, collected from Jvxian, Laizhou, and Wenshang in Shandong Province, China. All samples were cut into $\phi 50 \times 100 \mathrm{~mm}$ with a surface parallelism value of within $0.05 \mathrm{~mm}$, in correspondence with the ISRM standard [41]. No visible flaws were observed on the sample surfaces.

2.2. Experimental Apparatus and Methods. The experimental setup included WAW-600, a furnace, and a temperature controller. As in previous studies [42], all specimens were oven-dried for $24 \mathrm{~h}$ at $105^{\circ} \mathrm{C}$ to remove moisture. A temperature controller was used to heat the specimens at a rate of $2^{\circ} \mathrm{C} / \mathrm{min}$, ensuring a homogenous internal and external sample temperature, which is more representative of a natural setting. Furthermore, fast heating rates lead to larger thermal stress, which is beyond the scope of the present study.

Samples were held at the target temperature for 2 hours to allow for equilibration [43] and then compressed at a rate of $0.5 \mathrm{MPa} / \mathrm{s}$ until the sample fails. Tests were performed at room temperature $\left(25^{\circ} \mathrm{C}\right), 200^{\circ} \mathrm{C}, 400^{\circ} \mathrm{C}, 600^{\circ} \mathrm{C}$, and $800^{\circ} \mathrm{C}$, respectively. Additional temperature points were added when appropriate to better constrain the UCS variation. At least three samples were tested at each temperature point.

\section{Results}

3.1. Rock Stress-Strain Characteristics. The uniaxial compression results for each rock type are shown in Figure 1. The stress-strain behaviours and failure photographs of sandstone are quite different from that of marble during the 


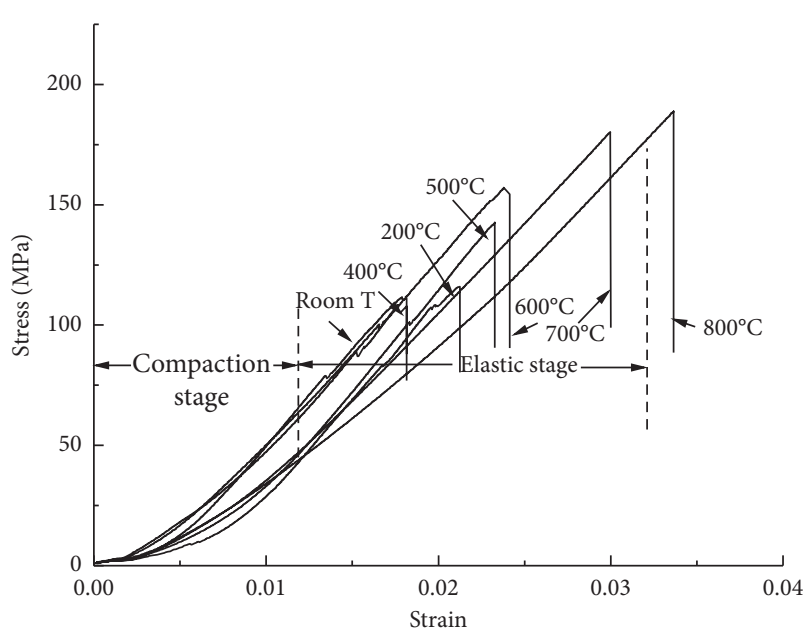

(a)

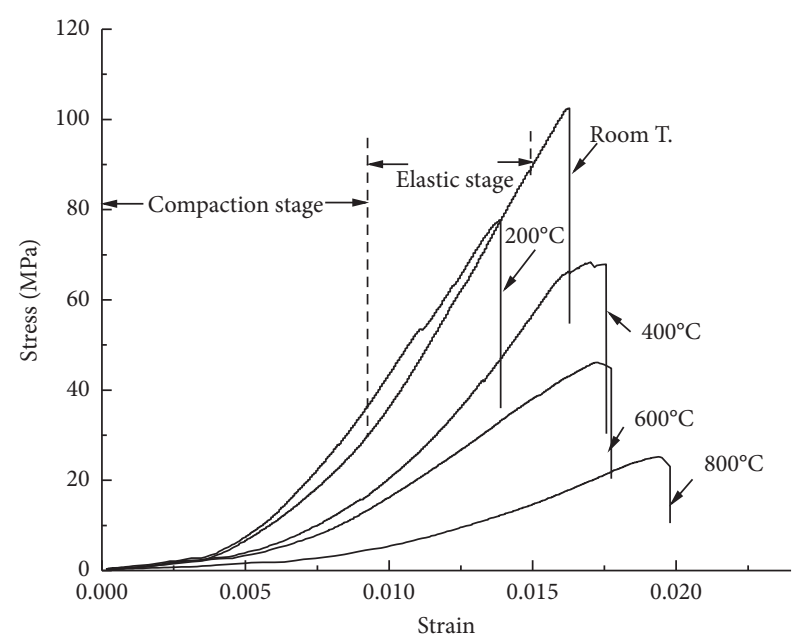

(c)

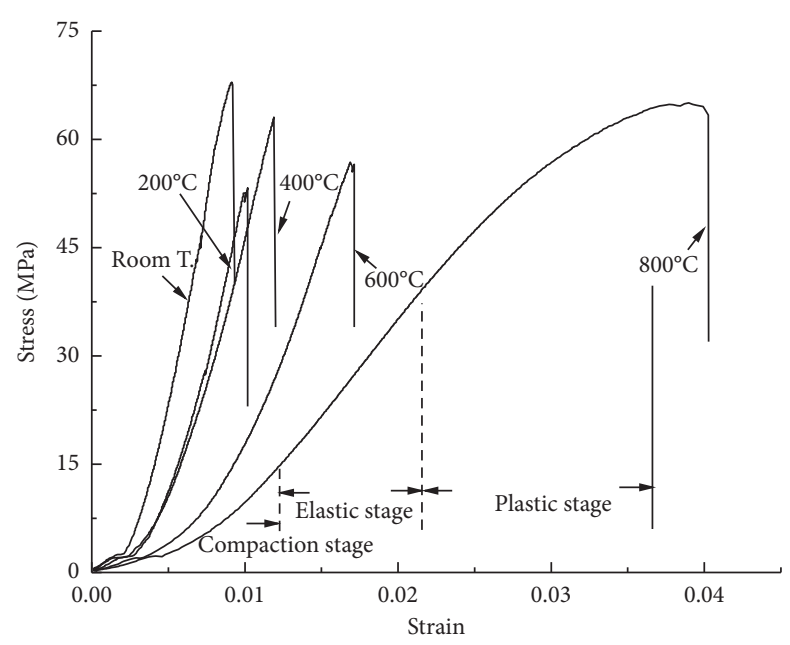

(b)

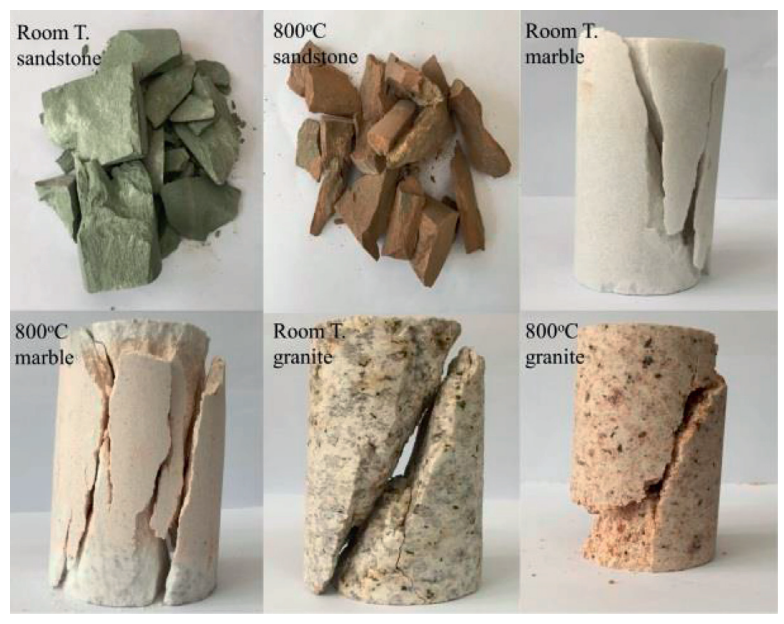

(d)

Figure 1: Stress-strain curve and failure photographs of rock samples as a function of temperature: (a) sandstone samples, (b) marble samples, (c) granite samples, and (d) failure photograph.

compaction and elastic stages at the same temperature (Figure 1). The stress-strain curve of marbles clearly shows a ductile stage at $800^{\circ} \mathrm{C}$, as shown in Figure 1. Figure 2 shows the peak strain of rock samples at different temperatures. Before $800^{\circ} \mathrm{C}$, failure pictures are similar for all temperature points.

The characteristics of peak strain variation can be summarized as follows.

The sandstone peak strain rises by $85.3 \%$ from 0.01815 at $25^{\circ} \mathrm{C}$ to 0.03364 at $800^{\circ} \mathrm{C}$. However, no distinct plastic stage is observed after the elastic stage on the stress-strain curve (Figure 1(a)), which indicates that the failure mode of sandstone remains brittle over this temperature range.

For marbles, the peak strain increases by $325 \%$ from 0.0092 at $25^{\circ} \mathrm{C}$ to 0.0391 at $800^{\circ} \mathrm{C}$. The stress-strain curves in Figure 1(b) demonstrate the distinct failure mode transition from brittle to ductile between $600^{\circ} \mathrm{C}$ and $800^{\circ} \mathrm{C}$.

The granite peak strain increases only by $33.36 \%$ from 0.01484 at $25^{\circ} \mathrm{C}$ to 0.01979 at $800^{\circ} \mathrm{C}$ with a continuous decrease in the peak stress. At $800^{\circ} \mathrm{C}$, the compaction stage of the stress-strain curve is extended and the elastic stage is shortened, which implies that a subsequent transition from brittle to ductile failure modes occurs at the higher temperature.

3.2. Variation Characteristics of Rock Uniaxial Compressive Strength. The UCS is the peak stress experienced by a rock sample during the loading process. Variations in average UCS are plotted in Figure 3.

From which, the following characteristics can be summarized.

The UCS of sandstone samples below $400^{\circ} \mathrm{C}$ decreases gradually with the temperature from $117.16 \mathrm{MPa}$ at $25^{\circ} \mathrm{C}$ to 108.62 $\mathrm{MPa}$ at $200^{\circ} \mathrm{C}$ and $107.3 \mathrm{MPa}$ at $400^{\circ} \mathrm{C}$. However, above $400^{\circ} \mathrm{C}$, UCS values increase sharply, reaching $196.63 \mathrm{MPa}$ at $800^{\circ} \mathrm{C}$. Compared with values at room temperature, sandstone UCS changes by $34.5 \%, 36.4 \%, 45.4 \%$, and $67.8 \%$ at 200,400 , 600 , and $800^{\circ} \mathrm{C}$, respectively. Therefore, the reversal point should be in the range of $400^{\circ} \mathrm{C}$ to $500^{\circ} \mathrm{C}$. 


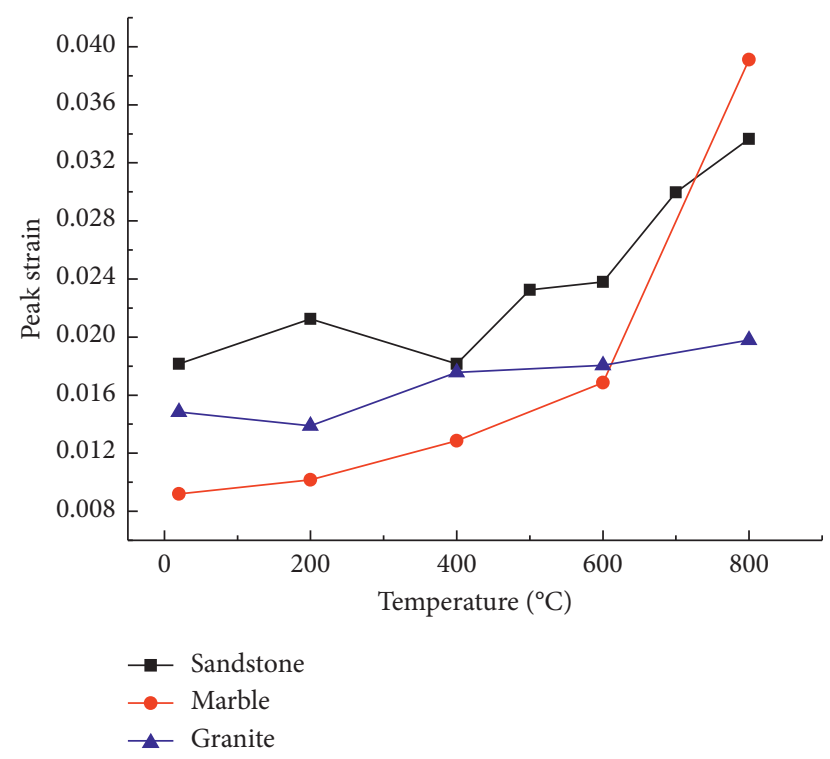

Figure 2: Peak strain for the three rock samples as a function of temperature.

The UCS of marble samples decreases linearly with temperature to a minimum of $55.84 \mathrm{MPa}$ at $600^{\circ} \mathrm{C}$ and then increases slightly to $64.45 \mathrm{MPa}$ at $800^{\circ} \mathrm{C}$. Granites' UCS decreases with temperature to $32.3 \mathrm{MPa}$ at $800^{\circ} \mathrm{C}$, a reduction of about $70 \%$ from that at the room temperature.

In summary, the effect of temperature on UCS is strongly dependent on the rock type. Marbles' UCS values demonstrate only slight changes with an increase in the temperature, while the sandstone behaves quite differently above $400^{\circ} \mathrm{C}$ with a sharp increase in UCS. Below $400^{\circ} \mathrm{C}$, the UCS of both types of rocks decreases slightly, demonstrating a weak temperature effect over this interval. Temperature effect above $400^{\circ} \mathrm{C}$, however, is markedly different for each type of the rocks and therefore requires appropriate consideration.

3.3. Variation Characteristics of Rock Elastic Modulus. The elastic modulus is an important rock mechanical parameter commonly used in rock engineering. The elastic modulus can be calculated as a linear fitting to the stressstrain curve. In this study, we fit curves to values from $30 \%$ to $70 \%$ of the rock UCS. Elastic modulus variations are plotted in Figure 4. In general, the elastic modulus of all samples decreases, while each type of the rock demonstrates its own specific characteristics.

The elastic modulus of sandstone samples increases from $7.97 \mathrm{GPa}$ at $400^{\circ} \mathrm{C}$ to $8.69 \mathrm{GPa}$ at $500^{\circ} \mathrm{C}$, both of which are lower than the value $9.17 \mathrm{GPa}$ at the ambient temperature. From Figure 1, it is observed that sandstone's UCS increases sharply at $500^{\circ} \mathrm{C}$ with a stronger temperature dependence than that of the peak strain, which results in the small increase in the sandstone elastic modulus. These results are also indicative of strengthening of the sandstone mechanical properties.

The elastic modulus of marbles decreases linearly from $10.03 \mathrm{GPa}$ at $25^{\circ} \mathrm{C}$ to $2.5 \mathrm{GPa}$ at $800^{\circ} \mathrm{C}$. Although the marble
UCS increases between 600 and $800^{\circ} \mathrm{C}$, the peak strain over the full temperature range increases by about a factor of four, and the decrease in elastic modulus is observed.

The elastic modulus of granite samples generally decreases with temperature from $10.47 \mathrm{GPa}$ at room temperature to $3.32 \mathrm{GPa}$ at $800^{\circ} \mathrm{C}$. The elastic modulus at $400^{\circ} \mathrm{C}$ is higher than those values at $200^{\circ} \mathrm{C}$, which we speculate to be due to mechanical property changes at this temperature that increase the data scatter.

Although the elastic modulus of both rock samples decreases with temperature, each rock type shows markedly different magnitudes. The elastic modulus of marbles decreases by several times compared with their ambient temperature, while the sandstone elastic modulus decreases by about $25 \%$. The UCS values of marbles decrease and peak strain increases with temperature, while sandstone UCS values increase sharply above $500^{\circ} \mathrm{C}$. The variations of the rock elastic modulus are influenced by the combined effect of rock strain and UCS.

\section{Analysis and Discussion}

Previous investigations have shown that rock mechanical properties may change at high temperature due to the evaporation of free water, microcrack propagation, mineral dehydration, decomposition, and phase changes [37, 44]. A number of tests have been conducted to evaluate the internal relationship between rock mechanical parameters and external factors.

4.1. Rock Uniaxial Compression Strength (UCS). The temperature threshold for the $\alpha-\beta$ quartz phase change is $573^{\circ} \mathrm{C}$ [7], and the temperature threshold for the decomposition of calcium carbonate is about $800^{\circ} \mathrm{C}$ [15]. These phenomena would therefore not contribute to the increasing UCS trend observed in sandstone samples above $500^{\circ} \mathrm{C}$. Furthermore, thermal cracking during heating leads to the propagation of microcracks that also diminishes rock bearing capacity.

The mineral composition of sandstone samples was measured by X-ray diffraction (XRD) (Table 1) and found to contain quartz, potassium feldspar, and TCCM (kaoline, etc., clay minerals), similar to the raw materials found in many ceramics. When temperature reached $450^{\circ} \mathrm{C}$, the mineral of $\mathrm{Fe}^{2+}$ in sandstone experiences the following chemical reaction. In the process, the colour of sandstone changes from greyish-green into red (Figure 1(d)). Compared with the previous research work [45], the composition of sandstone is $20 \%$ mica, $30 \%$ kaolinite, $30 \%$ quartz, $15 \%$ albite, and $10 \%$ siderite, which is different with the contents of sandstone in this paper. Under real-time heating, no sintering reaction as following was found in that study, and thus sandstone UCS experienced a decreasing trend after $400^{\circ} \mathrm{C}$ rather than a sharp increasing trend:

$$
\mathrm{Fe}^{2+}+\mathrm{O}_{2} \stackrel{400-800 C^{\circ}}{\longrightarrow} \mathrm{Fe}_{2} \mathrm{O}_{3}
$$

In the manufacture of certain ceramics, the percentage of potassium feldspar is usually $20 \%$ to $30 \%$, and the temperature for the sintering reaction is 0.5 to $0.8 \mathrm{Tm}$ 


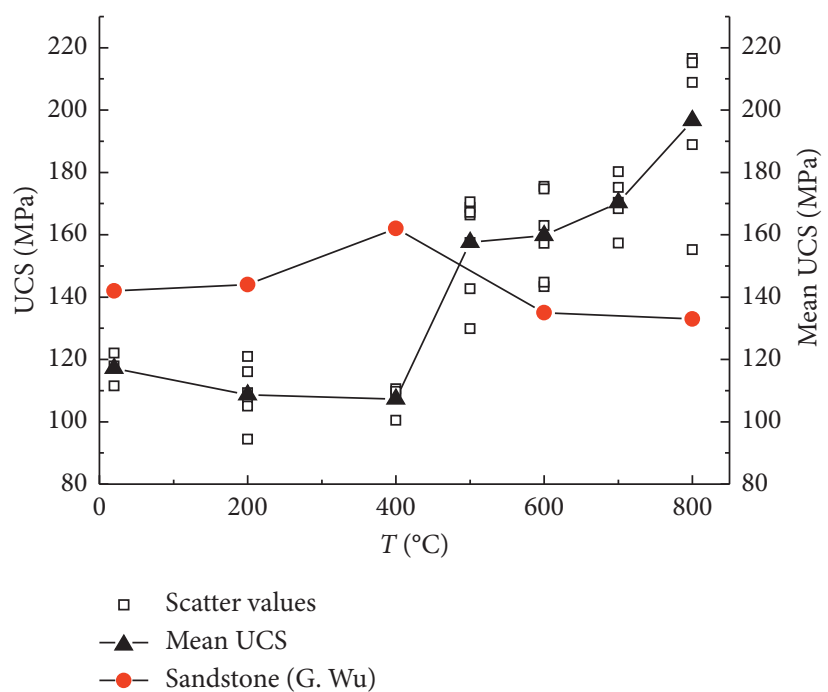

(a)

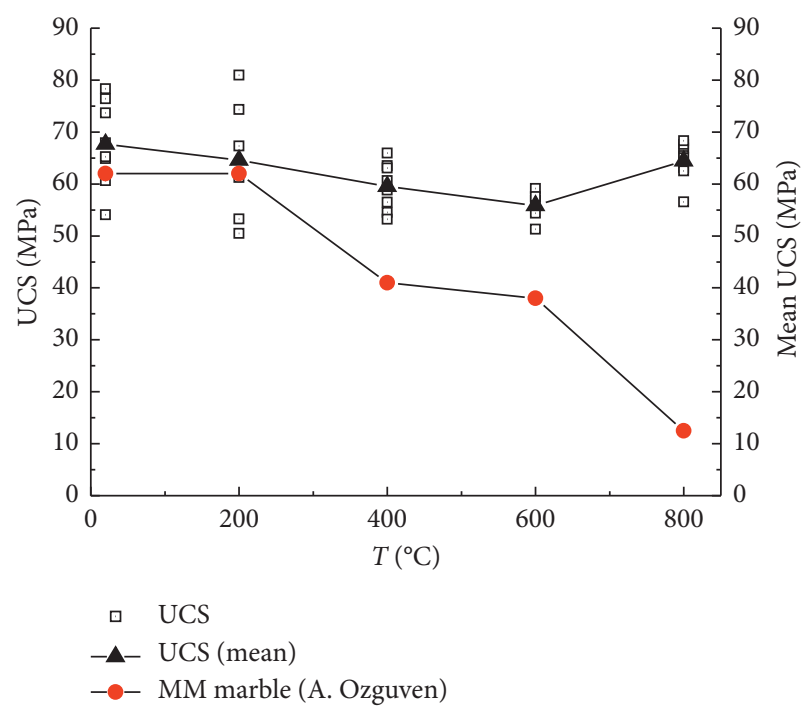

(b)

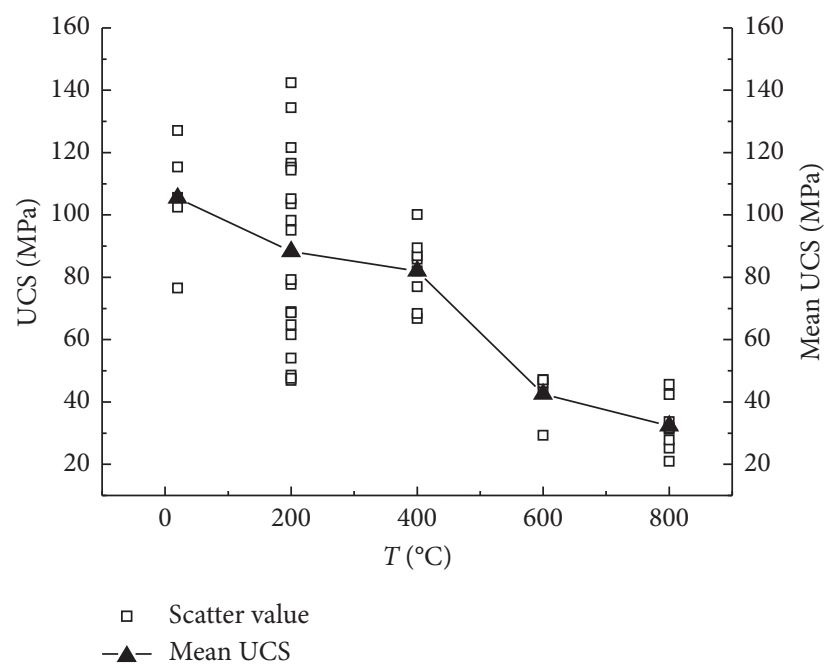

(c)

Figure 3: Variation of rock uniaxial compressive strength with temperature: (a) sandstone samples, (b) marble samples, and (c) granite samples.

where $\mathrm{Tm}$ is the melting point of the raw material. The melting point of potassium feldspar is about $1150^{\circ} \mathrm{C}$, and the melting point of anorthose is between 1100 and $1150^{\circ} \mathrm{C}$. When the raw material is blended with $\mathrm{Al}_{2} \mathrm{O}_{3}$ and $\mathrm{Fe}_{2} \mathrm{O}_{3}$, the melting point further decreases to about $500^{\circ} \mathrm{C}[46,47]$. The sintering reaction in sandstone can be simply described as in Figure 5.

In the initial state, the crystal grain in sandstone is in loose contact; with temperature reaching about $500^{\circ} \mathrm{C}$, the generation of $\mathrm{Fe}$ and $\mathrm{Al}$ oxides gradually fills the space between crystal grains and then forms into a eutectic material under the effect of high temperature. After that, the feldspar in sandstone samples gradually softens, causing an increase in the peak strain of sandstone, and then melts into this eutectic material until forming a new close contact crystal grain (shown in Figure 5(c)). In the whole process, the contact area between mineral grains is enlarged [48] and then leads to an increase in the sandstone UCS above $500^{\circ} \mathrm{C}$.

However, for marbles and granites, the internal mechanical mechanism is similar to sandstones below $600^{\circ} \mathrm{C}$ and $800^{\circ} \mathrm{C}$, respectively. Under the effect of real-time heating, thermal cracking induced by thermal stress and asymmetric thermal expansion prompts the propagation of microcracks and causes the decline in rock UCS. When the temperature reached $800^{\circ} \mathrm{C}$, the marble UCS slightly increases compared with values obtained from the previous work, which decreases sharply at $800^{\circ} \mathrm{C}$ [25]. In the process, the dolomite in marble decomposes into calcium oxide and magnesium oxide at about $800^{\circ} \mathrm{C}$; the marble composition is shown in Table 2. The decomposition of dolomite leads to a reduction in the size of crystal grains and increases the padding minerals between crystal grains, shown in Figure 6 . In this case, the main factor for controlling marble UCS is 


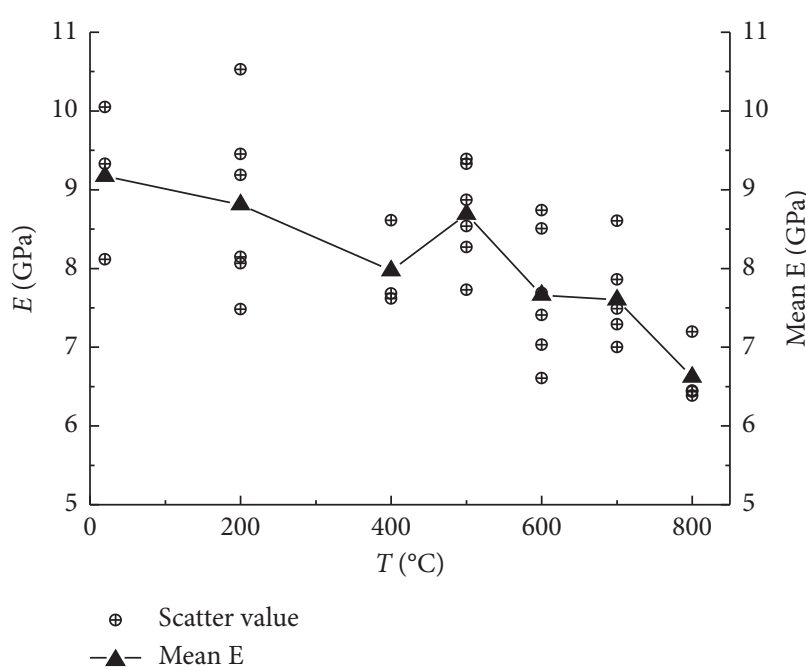

(a)

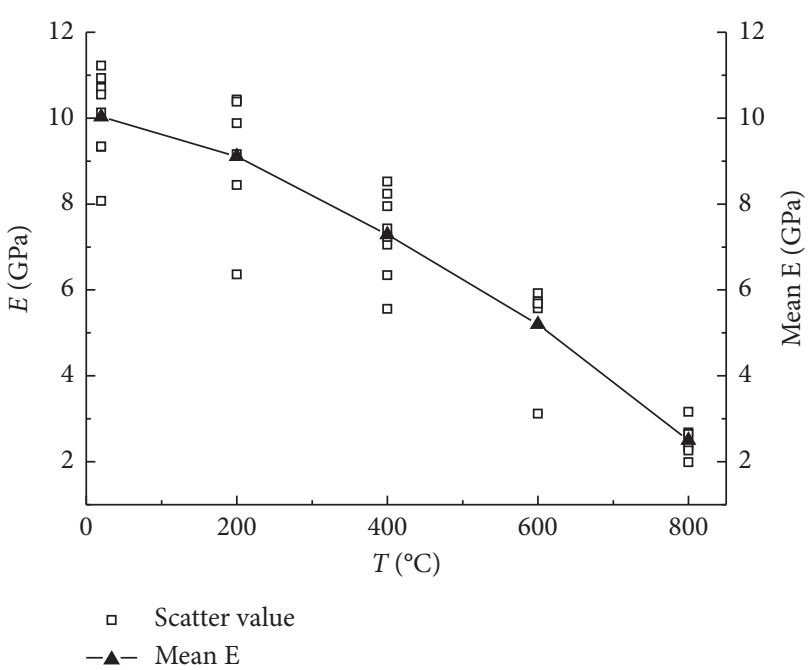

(b)

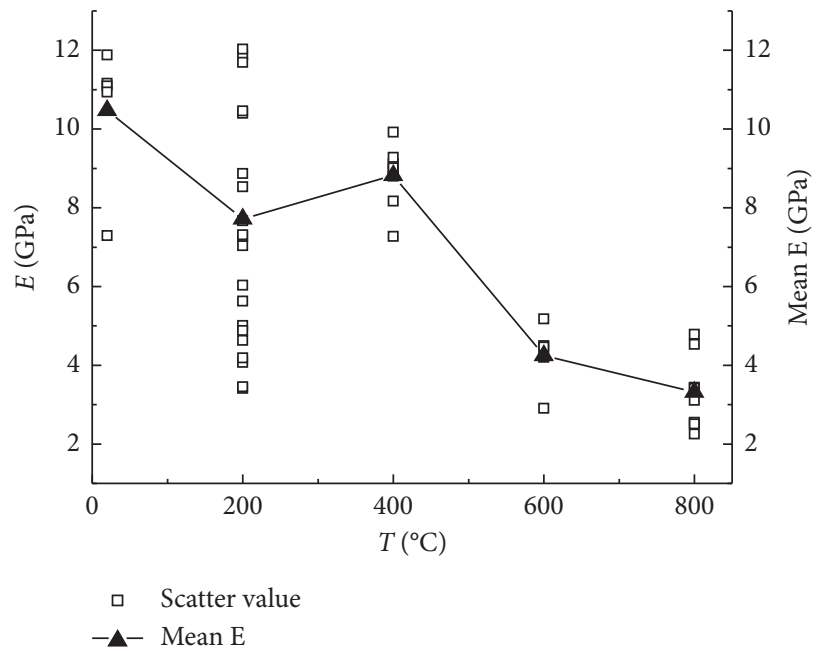

(c)

FIgURE 4: Change in the elastic modulus with temperature: (a) sandstone samples, (b) marble samples, and (c) granite samples.

TABLE 1: Mineral composition of sandstone used in this study.

\begin{tabular}{lcccccc}
\hline Mineral & Quartz & Potassium feldspar & Anorthose & Calcite & Dolomite & TCCM \\
\hline Content (\%) & 17.0 & 31.0 & 38.0 & 3.0 & 5.0 & 6.0 \\
\hline
\end{tabular}

TCCM means clay minerals in the XRD test.

the padding mineral produced by decomposition of dolomite, filling the space between crystal grains and then enlarging the friction between crystal grains during the loading process.

4.2. RockElastic Modulus. For the rock elastic modulus, they are all presenting a decreasing trend with temperature. Rock elastic modulus is a mechanical property to describe rock's ability to resist deformation. Under the real-time heating, all rock samples gradually soften which is represented by an increase in the rock peak strain. And, the failure mode of rock samples becomes from brittle failure to ductile failure.
It can be clearly seen at $800^{\circ} \mathrm{C}$ of marbles from its stressstrain curve. It is clear that all rock types experience a process of gradual softening under real-time heating which then diminishes the rock's ability to resist deformation.

From the above analysis, it is shown that the internal mechanism of different rock samples' mechanical properties with temperature has similarities and differences. They can be summarized as follows:

(1) Thermal cracking induced by thermal stress and asymmetric thermal expansion of crystal grains results in propagation of microcracks in all rock samples. Increase in the microcracks in rock samples 


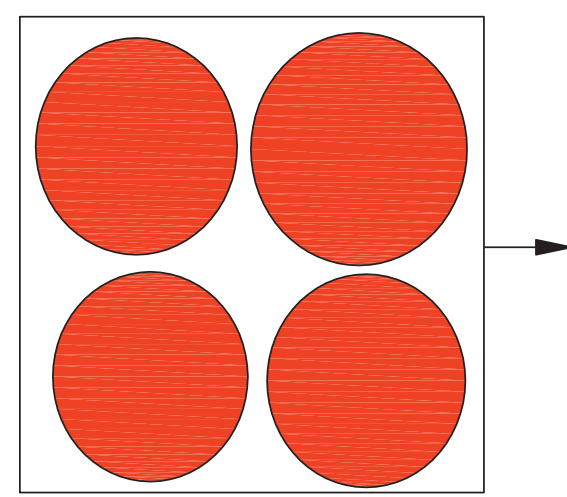

(a)

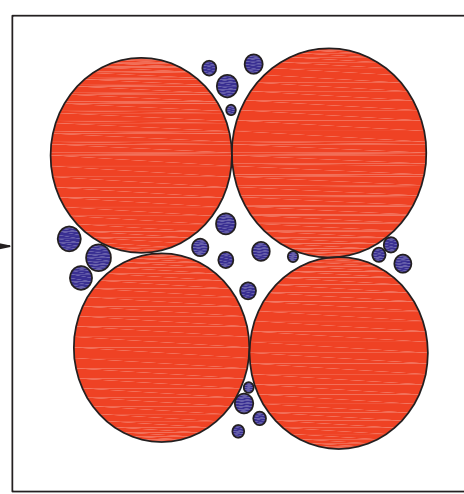

(b)

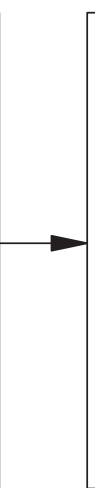

Crystal grain

$\mathrm{Fe}, \mathrm{Al}$ oxide

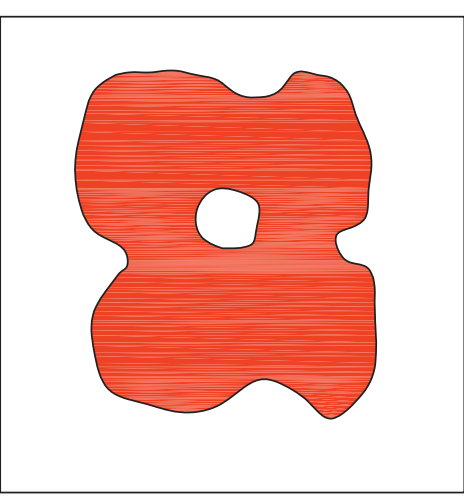

(c)

Figure 5: Schematic diagram of sintering reaction in sandstone: (a) initial state, (b) eutectic state, and (c) final state.

TABLE 2: Mineral composition of marble used in this study.

\begin{tabular}{lcccc}
\hline Mineral & Dolomite & Hornblende & White mica & Fe, $\mathrm{Al}$, etc. \\
\hline Content (\%) & 92.2 & 6.3 & 0.4 & 1.1 \\
\hline
\end{tabular}
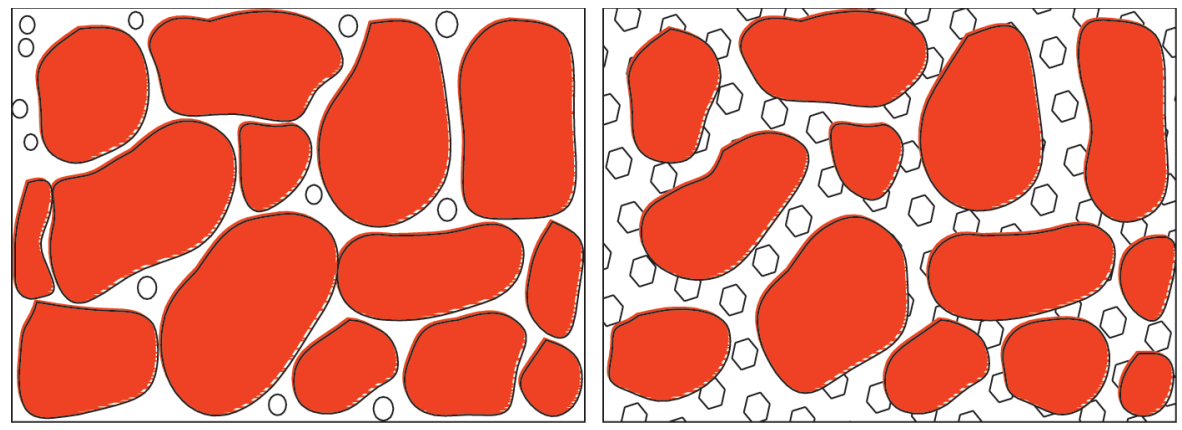

Crystal grain

圆 Padding minerals

Figure 6: Grain model of the marble sample in this paper.

weakens the rock bearing capacity. This is the reason why sandstone, marble, and granite experience a decreasing trend in their UCS below $400^{\circ} \mathrm{C}$, before $600^{\circ} \mathrm{C}$, and at the whole experimental temperature range, respectively.

(2) When the rock samples consisted of quartz, potassium feldspar, anorthose, clay minerals, etc., and in a proper percentage, the sintering reaction would exist under the effect of real-time heating. In the process, the melting and recombination of crystal grain prompt enlarging of the contact area between crystal grains and then strengthening of the rock bearing capacity. Due to the lack of clay minerals in granites (shown in Table 3), no sintering reaction exists in the whole heating process, and the granite UCS continuously declines.
TABle 3: Mineral composition of granite used in this study.

\begin{tabular}{lccc}
\hline Mineral & Quartz & Potassium feldspar & Anorthose \\
\hline Content (\%) & 33.0 & 23.0 & 44.0 \\
\hline
\end{tabular}

(3) When the majority of the composition of rock samples is carbonate, it decomposes at about $800^{\circ} \mathrm{C}$, and the generation of the related oxide filling the crystal grains would enhance the friction between crystal grains. In this case, rock bearing capacity may increase slightly compared with the last experimental temperature point.

(4) In the whole heating process, all rock crystal grains gradually soften and result in an increase in rock ductility. It can simply be demonstrated by the increase in the rock peak strain with temperature. It 
shows that the temperature will weaken the rock's ability to resist deformation.

When conducting underground rock engineering, for example, underground coal gasification, it is hard to measure and monitor the deformation of the coal roof, so theoretical and numerical calculation will be adopted to calculate the relative technical parameters. In this case, some conclusions like variations of sandstone mechanical properties and its internal mechanism are helpful to evaluate the safety and economy of the underground rock engineering.

\section{Conclusion}

In this paper, mechanical characteristics of three types of rocks representing igneous, sedimentary, and metamorphic rocks have been investigated up to $800^{\circ} \mathrm{C}$. We find that the internal mechanism of variations of mechanical properties for different rock types has similarities and differences. With the whole heating process, thermal cracking induced by thermal stress and asymmetric thermal expansion is the main controlled factor to influence the rock bearing capacity. In this case, sandstone, marble, and granite UCS experience a decreasing trend below $400^{\circ} \mathrm{C}, 600^{\circ} \mathrm{C}$, and $800^{\circ} \mathrm{C}$, respectively. When rock samples consisted of some particular minerals and proper percentage, like sandstone in this paper, the sintering reaction exists in these minerals under the effect of high temperature and results in enlarging the contact area between crystal grains. Then, the rock bearing capacity would be strengthened. Besides, decomposition of carbonate and generated oxide filling the space between crystal grains enlarge the friction of crystal grains, which would enhance rock bearing capacity, like marble UCS at $800^{\circ} \mathrm{C}$. For the rock's ability to resist deformation, due to the effect of temperature, all three types of rocks experience a decreasing trend in the elastic modulus. The softening of the crystal grain under high temperature prompts the ductility of rock samples and then weakens the rock's ability to resist deformation.

The variation of mechanical properties of three rock types illustrates the significant importance of the real-time temperature effect. When conducting underground rock engineering involving temperature, it is necessary to consider the temperature effect on rock mechanical parameters.

\section{Data Availability}

The data used to support the findings of this study are available from the corresponding author upon request.

\section{Conflicts of Interest}

The authors declare that there are no conflicts of interest regarding the publication of this paper.

\section{Acknowledgments}

This work was financially supported by the National Natural Science Foundation of China (51504236 and 51674242) and the Priority Academic Programme for the Development of Jiangsu Higher Education Institutions (PAPD).

\section{References}

[1] Y. Zhao, Z. Feng, Z. Feng, D. Yang, and W. Liang, "THM (Thermo-hydro-mechanical) coupled mathematical model of fractured media and numerical simulation of a 3D enhanced geothermal system at $573 \mathrm{~K}$ and buried depth 6000-7000 M," Energy, vol. 82, pp. 193-205, 2015.

[2] Z. Yin, W. Chen, H. Hao et al., "Dynamic compressive test of gas-containing coal using a modified split hopkinson pressure bar system," Rock Mechanics and Rock Engineering, vol. 53, no. 2, pp. 815-829, 2020.

[3] Z.-Q. Yin, Z.-X. Hu, Z.-D. Wei et al., "Assessment of blastinginduced ground vibration in an open-pit mine under different rock properties," Advances in Civil Engineering, vol. 2018, Article ID 4603687, 10 pages, 2018.

[4] K. Peng, S. Shi, Q. Zou, Y. Zhang, and G. Tan, "Gas permeability characteristics and energy evolution laws of gasbearing coal under multi-level stress paths," Natural Resources Research, vol. 1, pp. 1-22, 2020.

[5] G. Xie, Z. Yin, L. Wang, Z. Hu, and C. Zhu, "Effects of gas pressure on the failure characteristics of coal," Rock Mechanics and Rock Engineering, vol. 50, no. 7, pp. 1711-1723, 2017.

[6] Y.-L. Chen, J. Ni, W. Shao, and R. Azzam, "Experimental study on the influence of temperature on the mechanical properties of granite under uni-axial compression and fatigue loading," International Journal of Rock Mechanics and Mining Sciences, vol. 56, no. 15, pp. 62-66, 2012.

[7] Z.-J. Wan, Y.-S. Zhao, Y. Zhang, and C. Wang, "Research status quo and prospection of mechanical characteristics of rock under high temperature and high pressure," Procedia Earth and Planetary Science, vol. 1, no. 1, pp. 565-570, 2009.

[8] A. Ozguven and Y. Ozcelik, "Investigation of some property changes of natural building stones exposed to fire and high heat," Construction and Building Materials, vol. 38, no. 2, pp. 813-821, 2013.

[9] K. Peng, J. Zhou, Q. Zou, J. Zhang, and F. Wu, "Effects of stress lower limit during cyclic loading and unloading on deformation characteristics of sandstones," Construction and Building Materials, vol. 217, pp. 202-215, 2019.

[10] K. Peng, J. Zhou, Q. Zou, and F. Yan, "Deformation characteristics of sandstones during cyclic loading and unloading with varying lower limits of stress under different confining pressures," International Journal of Fatigue, vol. 127, pp. 82-100, 2019.

[11] K. Peng, J. Zhou, Q. Zou, and X. Song, "Effect of loading frequency on the deformation behaviours of sandstones subjected to cyclic loads and its underlying mechanism," International Journal of Fatigue, vol. 131, Article ID 105349, 2020.

[12] K. Peng, Y. Wang, Q. Zou, Z. Liu, and J. Mou, "Effect of crack angles on energy characteristics of sandstones under a complex stress path," Engineering Fracture Mechanics, vol. 218, Article ID 106577, 2019.

[13] Á. Török and M. Hajpál, "Effect of temperature changes on the mineralogy and physical proper ties of sandstones. a laboratory study," International Journal for Restoration of Buildings \& Monuments, vol. 11, no. 4, pp. 1-8, 2005.

[14] J. P. L. D. Santos, L. G. Rosa, and P. M. Amaral, "Temperature effects on mechanical behaviour of engineered stones," Construction \& Building Materials, vol. 25, no. 1, pp. 171-174, 2011. 
[15] S. Mccabe, B. J. Smith, and P. A. Warke, "Exploitation of inherited weakness in fire-damaged building sandstone: the "fatiguing" of "shocked" stone," Engineering Geology, vol. 115, no. 3-4, pp. 217-225, 2010.

[16] S. Liu and J. Xu, "An experimental study on the physicomechanical properties of two post-high-temperature rocks," Engineering Geology, vol. 185, no. 4, pp. 63-70, 2015.

[17] M. Li, X. Mao, L. Cao, H. Pu, R. Mao, and A. Lu, "Effects of thermal treatment on the dynamic mechanical properties of coal measures sandstone," Rock Mechanics and Rock Engineering, vol. 49, no. 9, pp. 3525-3539, 2016.

[18] G. Wu, Y. Wang, G. Swift, and J. Chen, "Laboratory investigation of the effects of temperature on the mechanical properties of sandstone," Geotechnical and Geological Engineering, vol. 31, no. 2, pp. 809-816, 2013.

[19] L. Zhang, X. Mao, and A. Lu, "Experimental study on the mechanical properties of rocks at high temperature," Science in China Series E: Technological Sciences, vol. 52, no. 3, pp. 641-646, 2009.

[20] H. Tian, T. Kempka, S. Yu, and M. Ziegler, "Mechanical properties of sandstones exposed to high temperature," Rock Mechanics and Rock Engineering, vol. 49, no. 1, pp. 321-327, 2016.

[21] B. Chakrabarti, T. Yates, and A. Lewry, "Effect of fire damage on natural stonework in buildings," Construction \& Building Materials, vol. 10, no. 10, pp. 539-544, 1996.

[22] V. Brotóns, R. Tomás, S. Ivorra, and J. C. Alarcón, “Temperature influence on the physical and mechanical properties of a porous rock: san Julian's calcarenite," Engineering Geology, vol. 167, no. 4, pp. 117-127, 2013.

[23] M. Y. Koca, G. Ozden, A. B. Yavuz, C. Kincal, T. Onargan, and K. Kucuk, "Changes in the engineering properties of marble in fire-exposed columns," International Journal of Rock Mechanics and Mining Sciences, vol. 43, no. 4, pp. 520-530, 2006.

[24] N. Sengun, "Influence of thermal damage on the physical and mechanical properties of carbonate rocks," Arabian Journal of Geosciences, vol. 7, no. 12, pp. 1-9, 2014.

[25] A. B. Yavuz and T. Topal, "Effects of different drying temperatures on the physical and mechanical properties of some marbles (Muğla, Turkey) during salt crystallization tests," Environmental Earth Sciences, vol. 75, no. 11, pp. 1-13, 2016.

[26] X.-B. Mao, L.-Y. Zhang, T.-Z. Li, and H.-S. Liu, "Properties of failure mode and thermal damage for limestone at high temperature," Mining Science and Technology (China), vol. 19, no. 3, pp. 290-294, 2009.

[27] H. Yavuz, S. Demirdag, and S. Caran, "Thermal effect on the physical properties of carbonate rocks," International Journal of Rock Mechanics and Mining Sciences, vol. 47, no. 1, pp. 94-103, 2010.

[28] K. Peng, Z. Liu, Q. Zou, Q. Wu, and J. Zhou, "Mechanical property of granite from different buried depths under uniaxial compression and dynamic impact: an energy-based investigation," Powder Technology, vol. 362, pp. 729-744, 2020.

[29] P. Kang, L. Hong, Y. Fazhi, Z. Quanle, S. Xiao, and L. Zhaopeng, "Effects of temperature on mechanical properties of granite under different fracture modes," Engineering Fracture Mechanics, vol. 226, Article ID 106838, 2020.

[30] P. Kang, L. Zhaopeng, Z. Quanle, Z. Zhenyu, and Z. Jiaqi, "Static and dynamic mechanical properties of granite from various burial depths," Rock Mechanics and Rock Engineering, vol. 52, no. 10, pp. 3545-3566, 2019.

[31] S. Liu and J. Xu, "Study on dynamic characteristics of marble under impact loading and high temperature," International
Journal of Rock Mechanics and Mining Sciences, vol. 62, no. 5, pp. 51-58, 2013.

[32] Q. Sun, W. Zhang, L. Xue, Z. Zhang, and T. Su, "Thermal damage pattern and thresholds of granite," Environmental Earth Sciences, vol. 74, no. 3, pp. 2341-2349, 2015.

[33] S. Liu and J. Xu, "Mechanical properties of qinling biotite granite after high temperature treatment," International Journal of Rock Mechanics and Mining Sciences, vol. 71, pp. 188-193, 2014.

[34] Y.-L. Chen, S.-R. Wang, J. Ni, R. Azzam, and T. M. Fernández-Steeger, "An experimental study of the mechanical properties of granite after high temperature exposure based on mineral characteristics," Engineering Geology, vol. 220, pp. 234-242, 2017.

[35] Y.-L. Chen, J. Ni, L.-H. Jiang, M.-L. Liu, P. Wang, and R. Azzam, "Experimental study on mechanical properties of granite after freeze-thaw cycling," Environmental Earth Sciences, vol. 71, no. 8, pp. 3349-3354, 2014.

[36] W. G. P. Kumari, P. G. Ranjith, M. S. A. Perera et al., "Hydraulic fracturing under high temperature and pressure conditions with micro CT applications: geothermal energy from hot dry rocks," Fuel, vol. 230, pp. 138-154, 2018.

[37] E. Althaus, A. Friz-Töpfer, C. Lempp, and O. Natau, "Effects of water on strength and failure mode of coarse-grained granites at 300 C," Rock Mechanics and Rock Engineering, vol. 27, no. 1, pp. 1-21, 1994.

[38] R. D. Dwivedi, R. K. Goel, V. V. R. Prasad, and A. Sinha, "Thermo-mechanical properties of Indian and other granites," International Journal of Rock Mechanics and Mining Sciences, vol. 45, no. 3, pp. 303-315, 2008.

[39] P. Vázquez, V. Shushakova, and M. Gómez-Heras, "Influence of mineralogy on granite decay induced by temperature increase: experimental observations and stress simulation," Engineering Geology, vol. 189, pp. 58-67, 2015.

[40] Y. Wang, X. Shang, and K. Peng, "Relocating mining microseismic earthquakes in a $3-\mathrm{D}$ velocity model using a windowed cross-correlation technique," IEEE Access, vol. 8, pp. 37866-37878, 2020.

[41] A. Aydin, ISRM Suggested Method for Determination of the Schmidt Hammer Rebound Hardness: Revised Version, Springer International Publishing, New York, NY, USA, 2008.

[42] A. W. Hatheway, "The complete ISRM suggested methods for rock characterization, testing and monitoring; 1974-2006," Environmental \& Engineering Geoscience, vol. 15, no. 1, pp. 47-48, 2009.

[43] Y. Zhao, Z. Wan, Z. Feng, D. Yang, Y. Zhang, and F. Qu, "Triaxial compression system for rock testing under high temperature and high pressure," International Journal of Rock Mechanics and Mining Sciences, vol. 52, no. 6, pp. 132-138, 2012.

[44] A. Ozguven and Y. Ozcelik, "Effects of high temperature on physico-mechanical properties of Turkish natural building stones," Engineering Geology, vol. 183, pp. 127-136, 2014.

[45] W. U. Zhong, B. D. Qin, L. J. Chen, and Y. J. Luo, "Experimental study on mechanical character of sandstone of the upper plank of coal bed under high temperature," Chinese Journal of Rock Mechanics \& Engineering, vol. 24, no. 11, pp. 1863-1867, 2005.

[46] W. Wang, Z. Fu, H. Wang, and R. Yuan, "Influence of hot pressing sintering temperature and time on microstructure and mechanical properties of TiB2 ceramics," Journal of the European Ceramic Society, vol. 22, no. 7, pp. 1045-1049, 2002. 
[47] J. Martín-Márquez, J. M. Rincón, and M. Romero, "Effect of firing temperature on sintering of porcelain stoneware tiles," Ceramics International, vol. 34, no. 8, pp. 1867-1873, 2008.

[48] Y. Ma, C. Bao, J. Chen, S. Song, and L. Han, "Study on microstructures and mechanical properties of foam titanium carbide ceramics fabricated by reaction sintering process," Journal of Materials Engineering \& Performance, vol. 27, no. 11, pp. 1-8, 2018. 